\title{
Modeling the growth dynamics of Antarctic krill Euphausia superba
}

\author{
Eileen E. Hofmann*, Cathy M. Lascara \\ Center for Coastal Physical Oceanography, Crittenton Hall, Old Dominion University, Norfolk, Virginia 23529, USA
}

\begin{abstract}
A time-dependent, size-structured, bioenergetically based model was developed to examine the growth dynamics of Antarctic krill Euphausia superba 2 to $60 \mathrm{~mm}$ in size. The metabolic processes included in the model are ingestion, a baseline respiration, respiratory losses due to feeding and digestion, and an activity-based respiration factor. The total of these processes, net production, was used as the basis for determining the growth or shrinkage of individuals. Size-dependent parameterizations for the metabolic processes were constructed from field and laboratory measurements. Environmental effects were included through time series of pelagic phytoplankton concentration that were derived from data sets collected west of the Antarctic Peninsula. Simulated growth rates during the spring and summer for all krill size classes were consistent with published growth rates; however, initial results indicated that winter shrinkage rates were too large. Although the use of a seasonally varying respiration activity factor (reduced winter respiration rates) resulted in winter shrinkage rates of adults that were consistent with observations of experimentally starved individuals, the annual change in length of specific size classes was still inconsistent with observations. Subsequent simulations examined the effect of ingestion of sea ice algae by krill in the late winter and early spring. The annual growth cycle best matched observations, particularly those for larval and subadult krill $(<35 \mathrm{~mm})$, when reduced winter respiration rates and ingestion of sea ice algae were both included. These results suggest that the ability of krill to exploit a range of food sources and reduced winter metabolism rates are the mechanisms that allow krill to successfully overwinter. The need for additional observations of krill physiological processes, especially during winter, is clearly indicated.
\end{abstract}

KEY WORDS: Antarctic krill · Bio-energetic model · Overwinter strategies

\section{INTRODUCTION}

Antarctic krill Euphausia superba has long been recognized as an important component of the Antarctic marine food web (Fraser 1936, Marr 1962). As a consequence, much effort has gone into the study of the distribution, life history, physiology, and behavior of this species (e.g. Miller \& Hampton 1989, El-Sayed 1994). In particular, the strategy by which the long-lived, up to 5 yr (e.g. Ettershank 1983, Miller \& Hampton 1989), Antarctic krill survive the winter has been a topic of debate for some time. It has been assumed that the low pelagic phytoplankton biomass resulting from the reduced light and extensive ice cover characteristic of the Antarctic winter was insufficient to sustain krill.

\footnotetext{
•E-mail: hofmann@ccpo.odu.edu
}

Also, the lipid content of Antarctic krill is low and contains only traces of wax esters (Ikeda \& Dixon 1982, Clarke 1984), which makes lipid storage an unlikely energy reserve for overwintering krill. Strategies such as starvation, body shrinkage, and reduced metabolism have been proposed as the mechanisms that allow Antarctic krill to overwinter.

Laboratory studies (Ikeda \& Dixon 1982, Nicol et al. 1992) show that, when starved or exposed to low food concentrations, krill do shrink. Some field observations (Quetin \& Ross 1991) suggest that, during winter, individual krill exhibit lowered metabolic rates and shrinkage. These laboratory and field observations have been used to support the conclusion that body shrinkage is the primary mechanism by which Antarctic krill conserve energy and survive the long period of depleted pelagic food in winter. However, body shrinkage as an overwintering strategy is at odds with 


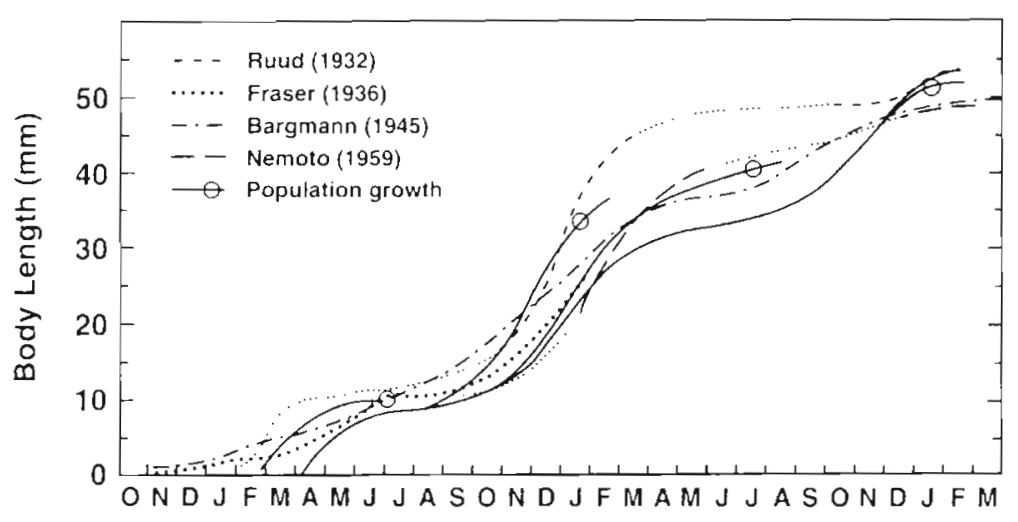

Fig. 1. Euphausia superba. Curves of population growth for Antarctic krill derived from field observations of length frequency distributions. Sources used in the analysis are indicated and the solid line represents the population growth curve developed by Mackintosh (1972) for Antarctic krill populations at South Georgia. Circles indicate krill mean size in the South Georgia region. Figure adapted from Mackintosh (1972)

the limited observations of krill growth during winter (e.g. Morris \& Priddle 1984, Huntley et al. 1994) and recent experimental work that shows krill must feed during winter to maintain its observed $\mathrm{C}: \mathrm{N}$ ratio and rates of ammonium excretion (Huntley et al. 1994, Huntley \& Nordhausen 1995). Also, early estimates of krill growth over time (Fig. 1), derived from analyses of length frequency for local Antarctic krill populations, suggest that these individuals have little-to-no length increase during winter and a length at the start of the following spring that is similar to their prewinter length. These observations imply a low level of feeding, reduced metabolism, or both throughout the winter, suggesting that the strategy by which krill survive the winter is likely complex. Mathematical modeling provides one approach for evaluating the relative effects of the different processes that contribute to krill growth in winter and throughout the year.

Astheimer et al. (1985) and Astheimer (1986) present a model of the growth of individual krill, which used a pre-defined growth function, derived from age-length relationships obtained under optimal conditions, to describe krill growth under varying food conditions. This non-mechanistic approach did not explicitly include metabolic processes and the subsequent calculation of net production, which limits the application of the model. More recently, a physiologically based model was developed for the embryos and non-feeding stages of Antarctic krill (Hofmann et al. 1992). Similar models do not exist for the latter krill life history stages in spite of the numerous laboratory and field studies (see reviews by Clarke \& Morns 1983, Quetin et al. 1994) of the the processes affecting the energy budget of this animal.
In this study, a time-dependent, sizestructured, energetically based model was developed to simulate the growth and development of Antarctic krill from the Calyptopis I stage (first feeding stage) to maximum adult size. Since the model is size-structured, it incorporates the ontogenetic changes in physiology and behavior that occur as the individual ages. The model is used to provide a framework for testing the consistency of the experimental and laboratory measurements of krill metabolic processes and to evaluate the processes by which krill overwinter. Simulations were done to examine krill growth dynamics as forced by environmental conditions typical of the region west of the Antarctic Peninsula and observations from this region provide verification of the simulated krill growth patterns.

The krill model and approaches used to parameterize the metabolic processes are described in the next section. Simulations of the time-dependent growth of krill exposed to a range of environmental conditions are then given. The final sections evaluate the simulated krill growth patterns in terms of measured growth patterns and Antarctic environmental conditions.

\section{MODEL DESCRIPTION}

\section{Model equations}

The equation governing the time-dependent $(t)$ change in the number of krill individuals ( $N$ ) in a given size class, $j$, is written as

$$
\frac{\mathrm{d} N_{j}}{\mathrm{~d} t}=-\alpha_{j} N_{j}-\beta_{j} N_{j}+\alpha_{j-1} N_{j-1}+\beta_{j+1} N_{j+1}
$$

where each size class is defined by a length and carbon weight. The first 2 terms represent the loss of individuals from size class j due to either growth or shrinkage and the last 2 terms represent the gain of individuals in size class $j$ due to growth or shrinkage from adjacent size classes. The rate of transfer between size classes is given by the coefficients, $\alpha$ and $\beta$, which are determined by changes in net production based on carbon weight.

Net production in any size class, $N P_{j}$, is assumed to be the difference between assimilated ingestion $\left(A I_{1}\right)$ and respiration $\left(R_{j}\right)$ :

$$
N P_{j}=A I_{j}-R_{j}
$$

When $N P,>0$, the gain in krill biomass effects a transfer to the next larger size class $\left(\alpha_{1}>0\right.$ and $\left.\beta_{1}=0\right)$. 
For $N P_{j}<0$, the loss in krill biomass is represented by a transfer of individuals to the next smaller size class $\left(\alpha_{j}=0\right.$ and $\beta_{j}>0$ ). Thus, either $\alpha_{j}$ or $\beta_{j}$ is zero during each model time interval.

The model given by Eq. (1) was configured with 232 size classes to describe the life history of krill from $2 \mathrm{~mm}$ (Calyptopis I, first feeding stage) to $60 \mathrm{~mm}$ (maximum adult size), with a resolution of $0.25 \mathrm{~mm}$. The size class model was solved numerically using an Euler scheme with a time step of $0.5 \mathrm{~d}$, which ensured that krill mass and individuals were conserved over the duration of a simulation. Simulations were $500 \mathrm{~d}$ in length and were initialized with 200 individuals in a given size class. Definitions of the variables used in the model are provided in Table 1.
Table 1. Variable definitions and units used in the krill size class model

\begin{tabular}{|c|c|c|}
\hline Variable & Definition & Units \\
\hline$N$ & Number of individuals & None \\
\hline$\alpha$ & Rate of growing individuals & $d^{-1}$ \\
\hline$\beta$ & Rate of shrinking individuals & $d^{-1}$ \\
\hline$L$ & Length & $\mathrm{mm}$ \\
\hline WW & Wet weight & $\mathrm{mg}$ \\
\hline$D W$ & Dry weight & $\mathrm{mg}$ \\
\hline$C W$ & Carbon weight & $\min C$ \\
\hline NP & Net production & $\mathrm{mg} C \mathrm{~d}^{-1}$ \\
\hline A & Assimilation efficiency & Percentage \\
\hline$\gamma$ & Time spent feeding & Percentage \\
\hline$I^{\mathrm{cf}}$ & Ingestion rate, compression filtration & $\mathrm{mg} \mathrm{C} \mathrm{d}^{-1}$ \\
\hline$I^{19}$ & Ingestion rate, ice grazing & $\mathrm{mgCd} \mathrm{d}^{-1}$ \\
\hline$F^{\mathrm{di}}$ & Filtration rate, compression filtration & $\mathrm{m}^{3} \mathrm{~d}^{-1}$ \\
\hline$F^{\prime g}$ & Filtration rate, ice grazing & $m^{3} d^{-1}$ \\
\hline$P(t)$ & Pelagic phytoplankton concentration & $\mathrm{mgC} \mathrm{m}$ \\
\hline$S I(t)$ & Sea ice biota concentration & $\mathrm{mg} \mathrm{C} \mathrm{m} \mathrm{m}^{-3}$ \\
\hline$R^{s}$ & Standard respiration rate & $\mathrm{mgC} \mathrm{d}{ }^{-1}$ \\
\hline$R^{\prime}$ & Feeding activity factor & No units \\
\hline$R^{d}$ & Seasonal activity factor & No units \\
\hline
\end{tabular}

\section{Model parameterizations}

Observations from field and experimental studies were used to derive functional relationships of the processes affecting krill net production. All of these parameterizations are size-dependent and the form of the relationship changes with size in some cases, as would be expected for a model configured for a long-lived individual characterized by a complex life history.

Length, weight, and carbon conversions

Any modeling study that uses experimental observations as the basis for describing metabolic processes is faced with the need to convert among the many units used for measurement to a common unit. In this study, the model outputs are in terms of krill biomass, given as $\mathrm{mg} \mathrm{C}$, and length, given as mm. Thus, the first step in developing the krill size-structure model was to obtain conversion relationships which allow the model calculations and output to be consistent with measurements and to be compared with observations. The required conversion relationships between wet weight ( $W W, \mathrm{mg}$ ), length $(L, \mathrm{~mm})$, dry weight ( $D W, \mathrm{mg})$, and carbon weight ( $C W, \mathrm{mg}$ ) are given in Table 2 .

The $L: W W$ relationship (Table 2) for larval krill $<5 \mathrm{~mm}$ is from Ikeda (1984). Observations (Fig. 2A) from samples collected along the Antarctic Peninsula in 1991 and 1993 were used to construct a $L: W W$ relationship for juvenile, subadult, and adult krill (Table 2 ). This data set included measurements taken during all seasons and the best regressions were obtained by splitting the data into 2 groups based on body length: 10 to $40 \mathrm{~mm}$ and 40 to $60 \mathrm{~mm}$ (Table 2). The $W W$ of krill between 5 and $10 \mathrm{~mm}$ was obtained by spline interpolation between the $5 \mathrm{~mm}$ krill value from Ikeda (1984) and the $10 \mathrm{~mm}$ krill value from the observations. The $W W: D W$ relationship (Table 2) is from Ikeda \& Mitchell (1982). The $D W: C W$ relationship (Table 2) is based on regression analysis of individual measurements tabulated from several studies (Fig. 2B).

\section{Ingestion}

The primary mode of feeding exhibited by krill is the ingestion of pelagic phytoplankton in the water column (Marr 1962, Clarke 1984). In this model, ingestion using

Table 2 . Length $(L, \mathrm{~mm})$ to wet weight $(W W, \mathrm{mg})$, wet weight to dry weight $(D W, \mathrm{mg})$, and dry weight to carbon $(C W, \mathrm{mg})$ relationships used in the krill growth model. The krill size range over which the relationships apply and the source for each is indicated

\begin{tabular}{|lcl|}
\hline Equation & $\begin{array}{c}\text { Size range } \\
(\mathrm{mm})\end{array}$ & Source \\
\hline$W W=0.0470 L^{2.121}$ & $2-5$ & Ikeda (1984) \\
$W W=0.0072 L^{3.021}$ & $10-40$ & Fig. 2A \\
$W W=0.0016 L^{3.423}$ & $40-60$ & Fig. 2A \\
$D W=0.216 W W$ & $2-60$ & Ikeda \& Mitchell (1982) \\
$C W=0.366 D W^{1.037}$ & $2-60$ & Fig. 2B \\
\hline
\end{tabular}


compression filtration, $I^{\mathrm{cl}}$, is formulated as

$$
I_{j}^{\mathrm{cf}}=\gamma_{j} F_{j}^{\mathrm{cl}} P(t)
$$

where $\gamma_{j}$ and $F_{j}^{c i}$ are the time spent feeding and the filtration rate for size class $j$, respectively, and $P(t)$ is the time-varying phytoplankton concentration. Filtration rates for Antarctic krill have been estimated from numerous laboratory studies, using both constant volume and flow-through techniques (see review by Morris 1984). These observations indicate that $F^{\text {cf }}$ is a function of krill size; however, a wide range in filtration rate vaIues have been published for similar-sized krill. These
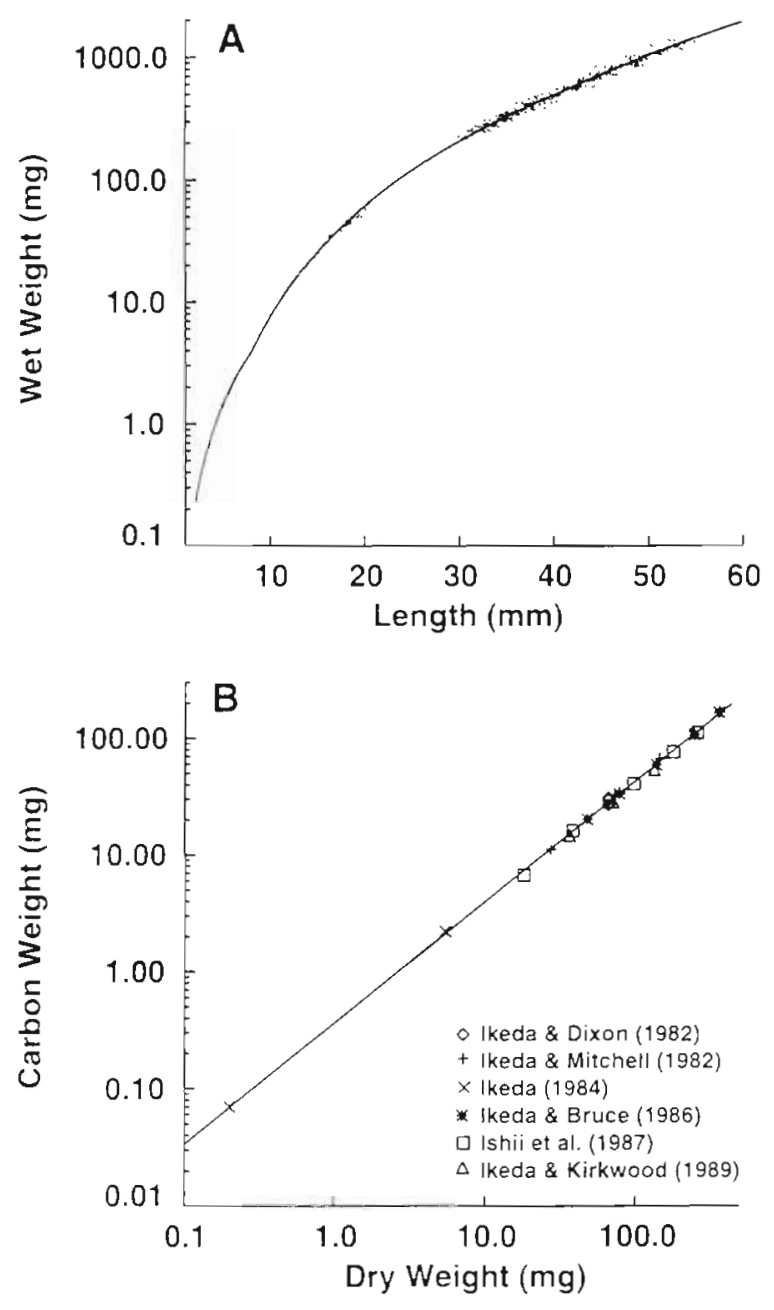

Fig. 2. Euphausia superba. (A) Observations (') of krill length (mm) and wet weight (mg) from samples collected along the Antarctic Peninsula in 1991 and 1993, as described in Lascara et al. (1999). Solid line is obtained from the regression equations provided in Table 2 . Regression for the 10 to $40 \mathrm{~mm}$ krill was based on $n=615$ with $r=0.995$. That for the 40 to $60 \mathrm{~mm}$ krill had $n=500$ and $r=0.951$. (B) Measurements of krill dry weight (mg) and carbon weight ( $\mathrm{mg}$ ) and the regression curve fit to these dala in $=23, r=0.999 j$. Equation for the curve is given in Table 2

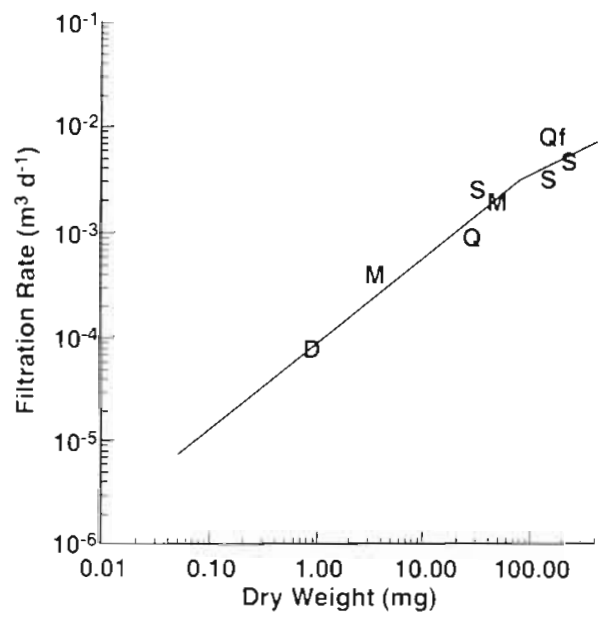

Fig. 3. Euphausia superba. Individual measurements of krill filtration rate as a function of dry weight given in: Schnack (1985) for mean filtration rate for 3 size classes of krill feeding on large centric diatoms (S); Daly (1990) for estimated filtration rate for $8 \mathrm{~mm}$ krill based on measurements of gut pigment and gut clearance time (D); Quetin \& Ross (1985) for maximum filtration rate for small adult (25 to $30 \mathrm{~mm}$ ) krill feeding on 2 large centric diatoms (Q); Quetin et al. (1994) for estimated filtration rate for adult krill based on field measurements of ingestion rate derived from gut fluorescence technique (Qf); Morris (1984) for constant volume filtration (M). Solid line indicates the curves fit to these measurements, and the equations for the curves are given in Table 3

differences have been attributed to inadequacies of experimental design, especially container size, and to the the type and concentration of food particles (Morris 1984, Quetin \& Ross 1985). The observations from several of the experimental studies were used to derive relationships between $F^{c t}$ and krill $D W$ (Fig. 3). These data allowed relationships to be determined for krill $<26 \mathrm{mg} \mathrm{DW}$ and $>84 \mathrm{mg} D W($ Fig. 3, Table 3). Filtration rates for krill not included in the regressions were obtained by a spline interpolation.

The parameter $\gamma$ includes the observations of krill as an animal which alternates between area-intensive

Table 3. Compression filtration $\left(F^{\mathrm{d}}, \mathrm{m}^{3} \mathrm{~d}^{-1}\right)$ and standard respiration rate $\left(R^{s}, \mu l \mathrm{~h}^{-1}\right)$ relationships used in the krill growth model. The krill dry weight range over which the relationshups apply and the source for each is indicated. The conversion used to obtain respiration rate in terms of $\mathrm{mg} \mathrm{C} \mathrm{d}^{-1}$ is given in the text

\begin{tabular}{|lcl|}
\hline Equation & Dry weight $(\mathrm{mg})$ & Source \\
\hline$F^{\mathrm{d}}=0.00085 D W^{0.825}$ & $<26$ & See text \\
$F^{\mathrm{d}}=0.00343 D W^{0.514}$ & $>84$ & See text \\
$R^{\mathrm{s}}=0.847 D W^{0.150}$ & $>6.3$ & Ikeda (1984) \\
$R^{\mathrm{s}}=0.686 D W^{1031}$ & $<1.5$ & See text \\
\hline
\end{tabular}


feeding and long-distance foraging movements (Hamner 1984). In the current time-dependent model, this parameter is specified as a constant with a value of 0.90 for larval krill $(<12 \mathrm{~mm})$ and 0.75 for larger krill ( $>12 \mathrm{~mm}$ ). In spatially explicit implementations of the size class model, this parameter can be specified to vary according to local phytoplankton concentrations.

Krill have also been observed to feed on the biota associated with sea ice (Marschall 1988, Stretch et al. 1988, Daly 1990). Underwater observations indicate that krill engage in an ice grazing behavior during which algal cells are scraped from the ice surface using the thoracic endopodites (Hamner et al. 1983). Ingestion of this food source is then accomplished by filtration using the thoracic appendages (Stretch et al. 1988). To date, no studies have been conducted to quantify the ingestion rate of krill feeding in this manner. In the absence of appropriate data, ingestion by grazing of sea ice biota, $I^{19}$, was formulated as

$$
I_{j}^{\mathrm{ig}}=\gamma_{j} F_{j}^{\mathrm{gg}} S I(t)
$$

where $S I(t)$ is the time-dependent sea ice algae concentration in $\mathrm{mg} \mathrm{C} \mathrm{m}^{-3}$ and $F_{j}^{\mathrm{ig}}$ is assumed to be $5 \%$ of $F_{j}^{\mathrm{cf}}$. This specification of $F_{j}^{\mathrm{g} g}$ results in $I^{\mathrm{ig}}$ rates for maximum values of $S I$, which are similar to $I^{\text {cf }}$ for average values of $P$.

Assimilated ingestion $\left(A I_{j}\right)$ was defined as the product of total $I\left(I^{\mathrm{cf}}+I^{\mathrm{ig}}\right)$ and an assimilation efficiency, $A$. $A$ was taken to be $80 \%$ for all krill size classes, which falls within the range ( 72 to $94 \%$ ) observed by Kato et al. (1982) for krill feeding on a variety of food types. The unassimilated ingestion is assumed to be lost as fecal pellets.

\section{Respiration}

Total respiratory metabolic loss for each size class $\left(R_{j}\right)$ was computed as standard metabolism $\left(R_{j}^{s}\right)$ plus increases due to feeding $\left(R_{j}^{f}\right)$ and decreases due to reduced activity levels in the winter $\left(R_{j}^{a}\right)$ :

$$
R_{j}=R_{j}^{s}\left(1+R_{j}^{f}+R_{j}^{\mathrm{a}}\right)
$$

This division of metabolic losses is consistent with current understanding of Antarctic krill energetics (Quetin et al. 1994, Torres et al. 1994a).

Several studies have reported standard metabolic rates based on measurements of oxygen uptake for subadult and adult krill (see review in Quetin et al. 1994). Most of these studies were conducted during the summer and express oxygen uptake as a function of krill size. The metabolic measurements of Ikeda (1984) were used to parameterize $R_{j}^{\text {s }}$ for krill size classes exceeding $6 \mathrm{mg} \mathrm{DW}$ (Fig. 4, Table 3), using a conversion ratio of $0.5357 \mathrm{ml} \mathrm{O}_{2}$ consumed $(\mathrm{mg} \mathrm{C})^{-1}$ which

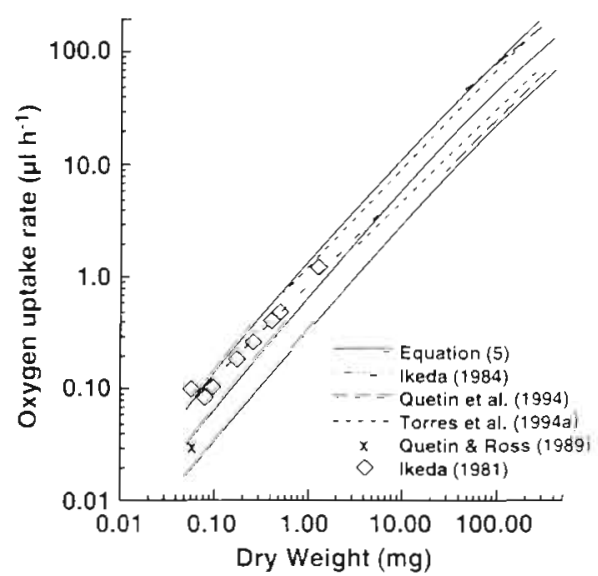

Fig. 4. Euphausia superba. Krill respiration rates as a function of dry weight. The 3 solid lines illustrate respiration relationships used in the model: the middle line is the standard metabolism ( $R^{\text {s }}$, see Table 3 for equations), the bottom line is the minimum respiration experienced by non-feeding krill in the winter, and the top line is the maximum respiration experienced by krill in summer feeding on daily ration of $10 \%$ krill weight. For comparison, the summer and winter respiration rates reported by Quetin et al. (1994) and Torres et al. (1994a) are shown. Larval respiration rates measured from individual experiments are shown, as is the extension of the respiration relationship from Ikeda (1984) to the smaller size krill. See text for details

assumes a respiratory quotient of 1.0 for protein metabolism (Ikeda \& Dixon 1982).

Metabolic measurements of larval krill are limited to 2 studies, Ikeda (1981) and Quetin \& Ross (1989). The data of Ikeda (1981) are consistent with the relationship defined for larger krill by Ikeda (1984); however, the respiration rate measured by Quetin \& Ross (1989) for first feeding larvae is much lower (Fig. 4). Initial simulations using the Ikeda (1984) $R_{j}^{\varsigma}$ relationship for all size classes resulted in very low or no growth for larval krill even at high food levels. Thus, a second regression (Fig. 4, Table 3) was used to parameterize $R_{j}^{\mathrm{s}}$ for krill size classes below $1.5 \mathrm{mg} D W$. This regression was selected to better match the measurements of Quetin \& Ross (1989) which provided reasonable growth rates for larval krill in subsequent simulations. Standard metabolism for size classes between 2 and $6 \mathrm{mg}$ $D W$ was determined by spline fit.

The metabolic cost of feeding was parameterized as a function of the daily ration ingested by krill as suggested by Ikeda \& Dixon (1984) to account for increased costs associated with specific dynamic action and feeding activity. For daily rations up to $10 \%$ of krill $C W, R_{f}^{f}$ increases linearly from 0 to 1 and remains constant for higher daily rations (Fig. 5A). Thus krill feeding at a daily ration equivalent to $5 \%$ incur total metabolic costs $\left(R_{\jmath}\right)$ which are 1.5 times higher than non-feeding krill (Fig. 4). 

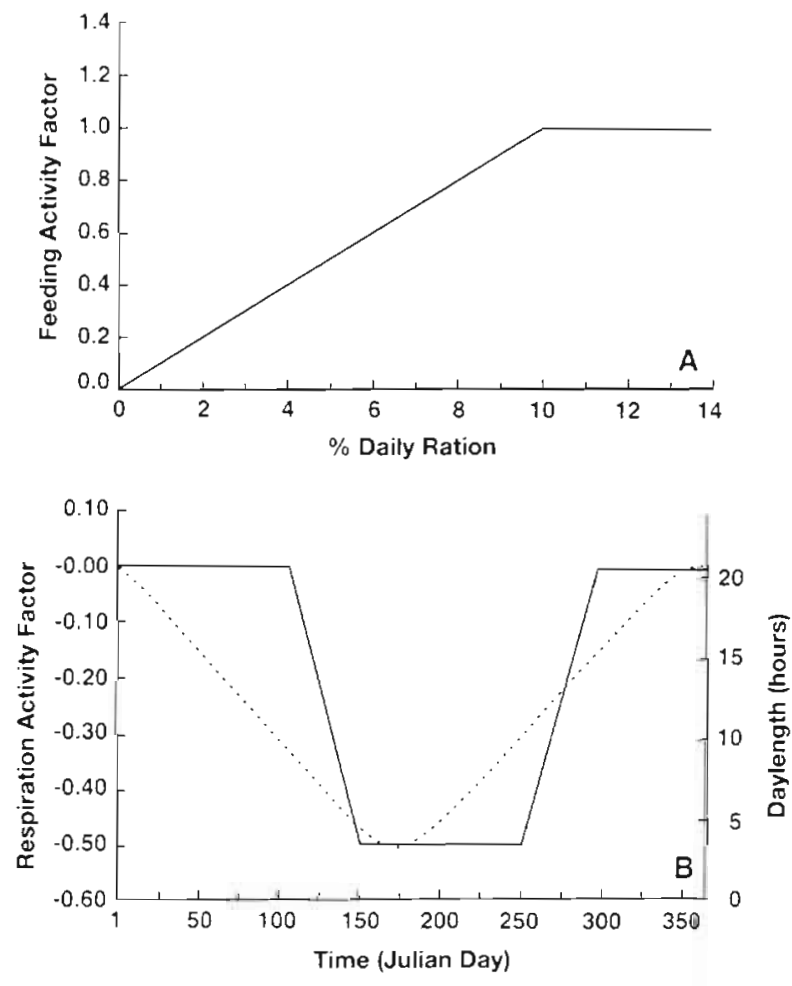

Fig. 5. Euphausia superba. (A) Feeding activity factor $\left(R_{j}^{\prime}\right)$ as a function of percent krill daily ration, calculated as ingestion/carbon weight, used to modify the standard respiration rate. (B) Seasonal activity factor $\left(R_{j}^{\mathrm{a}}\right.$, solıd line) used to compute total respiration cost. Dotted line shows the seasonal change in day length

Based on the growing evidence of reduced winter respiration rates for Antarctic krill (Ikeda \& Dixon 1982, Quetin \& Ross 1991, Torres et al. 1994a), the respiration activity factor, $R^{\mathrm{a}}$, was assumed to have a sea. sonal dependence such that, from Julian Day (JD) 150 through 250 (winter), $R^{a}$ is set to -0.5 , thus reducing total metabolism by $50 \%$ (Fig. SB). The minimum in respiration rate coincides with the minimum in day length. The transition between the winter and summer levels was assumed to be a linear decrease and increase, respectively, over a $45 \mathrm{~d}$ period. This parameterization results in total metabolic costs for nonfeeding krill during the winter which are consistent with observations from several experiments (Fig. 4).

\section{Environmental forcing}

As part of a long-term program designed to study the Antarctic marine ecosystem, numerous chlorophyll measurements have been made in the continental shelf waters west of the Antarctic Peninsula (Prézelin et al. in press). The chlorophyll measurements include all seasons and cover an area that extends from the inner shelf to beyond the shelf break. These data were used to construct 3 time series (Fig. 6), which represent pelagic phytoplankton concentrations on the outer shelf ( 0.1 to $\left.1.1 \mathrm{mg} \mathrm{chl} \mathrm{m}^{-3}\right)$, the inner shelf $(0.1$ to $2.0 \mathrm{mg} \mathrm{chl}$ $\left.\mathrm{m}^{-3}\right)$, and the coastal waters overlying the shelf $(0.1$ to $1.75 \mathrm{mg} \mathrm{chl} \mathrm{m} \mathrm{m}^{-3}$ ), where the outer shelf, coastal waters and inner shelf are defined as those regions beyond the $600 \mathrm{~m}$ isobath, between the 200 and $600 \mathrm{~m}$ isobath and inside the $200 \mathrm{~m}$ isobath, respectively. Comparisons with other measured chlorophyll values from this region (e.g. Holm-Hansen et al. 1989, Holm-Hansen \& Mitchell 1991) ensured consistency of the ranges and trends in the chlorophyll time series. The time series were used to specify the values for $P(t)$ in Eq. (3).

An additional chlorophyll time series (Fig. 6), which represented the algae available in sea ice from midAugust to early November (0 to $\left.20 \mathrm{mg} \mathrm{chl} \mathrm{m}^{-3}\right)$, was constructed from data available in Kottmeier \& Sullivan (1987), Stretch et al. (1988), Garrison \& Buck (1989), and Smith \& Sakshaug (1990). The asymmetry in the sea ice algae time series is consistent with the extended time for ice development and the rapid break-up of sea ice in the spring (Parkinson 1992, Jacobs \& Comiso 1997). This time series was used to specify values of $S I(t)$ in Eq. (4).

\section{RESULTS}

\section{Pelagic phytoplankton food source}

Larval krill, with an initial size of $2 \mathrm{~mm}$ on 1 February (JD 32), represent the result of the current season's spawn, since 20 to $30 \mathrm{~d}$ are required to complete development of the embryo and non-feeding larval stages (Hofmann et al. 1992). These krill increase in size during the first 3.5 mo when exposed to the 3 pelagic phytoplankton time series (Fig. 7). The range of increase is 3 to $6 \mathrm{~mm}$ for the low to high food concentrations, respectively. The simulated sizes during this time for the intermediate and high pelagic phytoplankton concentrations are consistent with measured values. Those produced by the low food concentrations consistently underestimate measured values. By the winter, the larval krill are 5 to $8 \mathrm{~mm}$ and remain at this size until late winter (August-September, JD 215-273). From mid-September to October, there is a slight decrease in larval krill size at all 3 food levels. In mid-December (JD 350), when increased food concentrations are again encountered, larval krill length increases rapidly, even at the lowest food concentrations. High food concentrations result in a tripling of the krill length.

The simulated growth of a $22 \mathrm{~mm}$ krill, which corresponds to the size of the $1^{+}$age class (subadult), shows an 


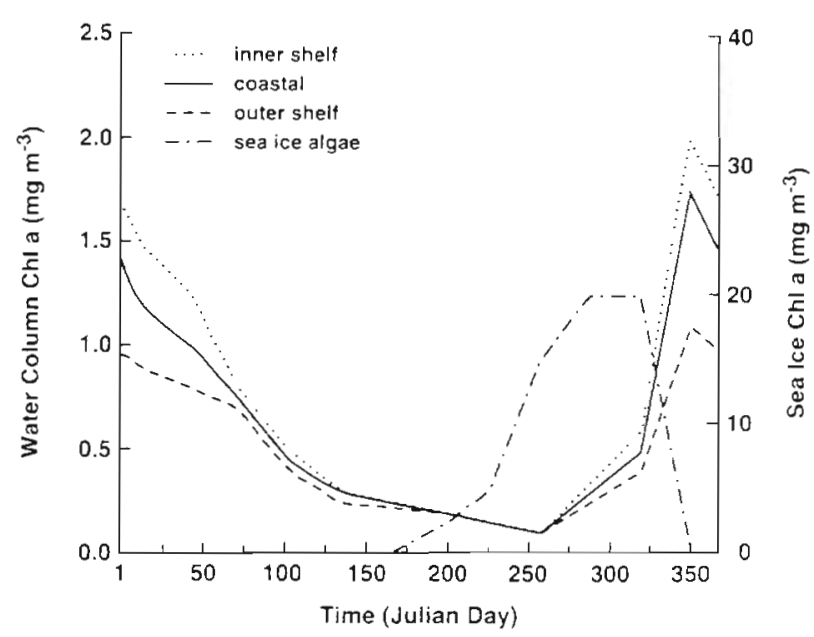

Fig. 6. Euphausia superba. Time series of the inner shelf, coastal, and outer shelf pelagic phytoplankton and sea ice algae concentrations used to provide the food supply for the krill size class model. Chlorophyll concentrations were converted to carbon using a C:chl ratio of 50

initial increase in length during the first $3.5 \mathrm{mo}$ (Fig. 7). However, the decreased chlorophyll levels in the fall and winter result in considerable shrinkage. Krill length increases rapidly in the late spring in response to the increase in pelagic chlorophyll concentrations. The effect of the different chlorophyll levels is most evident in the range of size produced in the krill at the end of the first year. The inner shelf chlorophyll values result in a doubling in krill length relative to the initial size. The coastal chlorophyll values give a factor of about 1.5 increase in $\mathrm{krill}$ length. The krill size at the end of 1 yr of simulation matches observed values (Fig. 7); however, the simulated winter krill lengths do not match observations.

Adult krill $(45 \mathrm{~mm})$ show a smaller variation in size over the time of the simulation (Fig. 7). When exposed to coastal phytoplankton values, these individuals maintain their size throughout the summer and decrease slightly into the fall. Their winter shrinkage gives a minimum size of $40 \mathrm{~mm}$, after which they increase to about $51 \mathrm{~mm}$ the following summer, after encountering the higher phytoplankton levels. This is an increase of about $13 \%$, relative to their initial size. For chlorophyll values characteristic of the outer shelf waters, the krill size at the end of $1 \mathrm{yr}$ of simulation is slightly smaller (44 $\mathrm{mm}$ ) than the starting size. The high chlorophyll values characteristic of inner shelf waters result in a $27 \%$ increase in krill size over the simulation.

\section{Pelagic phytoplankton and sea ice algae food source}

The inclusion of sea ice algae provides a winter food source for krill between August and November, when

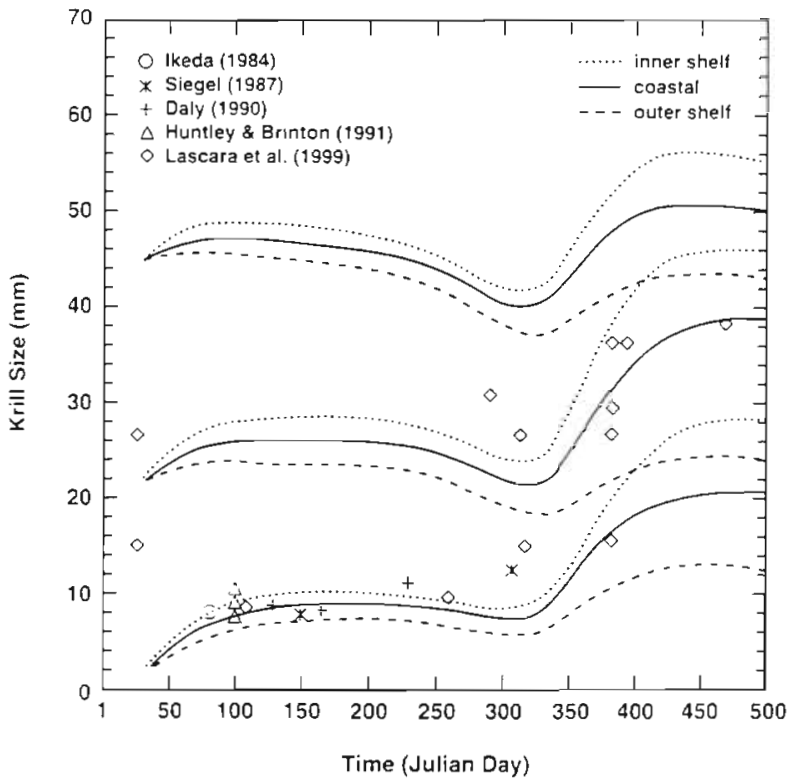

Fig. 7. Euphausia superba. Simulated time development of the dominant krill size class mode exposed to the 3 phytoplankton time series (cf. Fig. 6) for initial krill sizes of $2 \mathrm{~mm}$ (lower 3 curves), $22 \mathrm{~mm}$ (middle 3 curves), and $45 \mathrm{~mm}$ (upper 3 curves). The simulations start on 1 February (Julian Day, JD 32 ) and the symbols represent observed krill sizes that were obtained from field and laboratory experiments

the pelagic phytoplankton concentrations are low. Krill that begin at $2 \mathrm{~mm}$ in February (JD 32) increase in length throughout the fall and winter and reach 12 to $14 \mathrm{~mm}$ by the start of the next summer (Fig. 8). During the following summer, the krill grow and reach maximum sizes that range between 15 and $30 \mathrm{~mm}$ for the lowest to highest pelagic phytoplankton concentrations, respectively. The availability of a winter food source results in simulated winter and early spring krill sizes that match observations

Krill with an initial size of $22 \mathrm{~mm}$ show a slight decrease in size as the pelagic phytoplankton concentrations decrease in late fall and early winter (cf. Fig. 6) Once sea ice algae are available, this trend reverses and krill size increases by 5 to $6 \mathrm{~mm}$ during the winter. At the start of the following year, krill sizes range from 26 to $34 \mathrm{~mm}$, for the low to high phytoplankton concentrations, respectively. Again, a winter food source results in simulated winter and early spring krill sizes that match observations.

The pattern of growth (Fig. 8) for adult krill shows a moderate increase in size, 3 to $4 \mathrm{~mm}$, during the winter. This positions the krill to take advantage of the high phytoplankton concentrations the following spring. For the inner shelf phytoplankton concentrations, this allows krill to attain the maximum size (about $60 \mathrm{~mm}$ ) reported for this animal (Mackintosh 1972). 


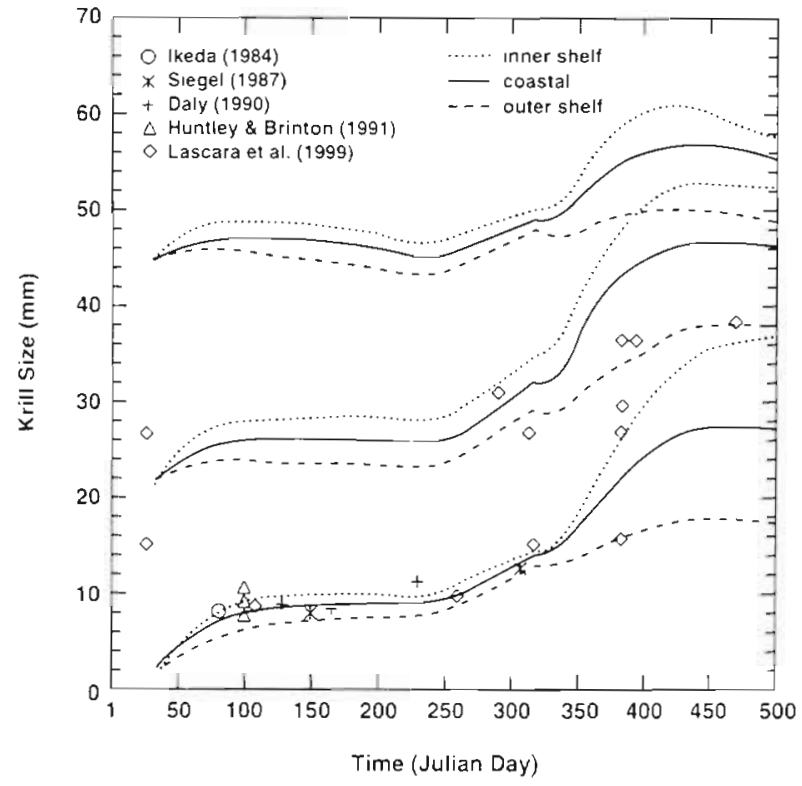

Fig. 8. Euphausia superba. Simulated time development of the dominant krill size class mode exposed to the 3 phytoplankton time series and the sea ice algae time series (cf. Fig. 6) for initial krill sizes of $2 \mathrm{~mm}$ (lower 3 curves), $22 \mathrm{~mm}$ (middle 3 curves), and $45 \mathrm{~mm}$ (upper 3 curves). The simulations start on 1 February (JD 32) and the symbols represent observed krill sizes that were obtained from field and laboratory experiments

\section{Growth rates}

The daily growth rates for $2 \mathrm{~mm}$ krill (Fig. 9A) range between 0.06 and $0.15 \mathrm{~mm} \mathrm{~d}^{-1}$, for the outer to inner shelf phytoplankton concentrations, respectively, during the first portion of the simulation. Growth rates in the late summer decrease, reach zero in fall, and become slightly negative during the winter. The negative winter growth rates arise because respiration costs during this time exceed the gain from assimilated ingestion, producing a negative net production, i.e. negative scope for growth. Thus, the krill shrinks. However, the addition of sea ice algae as a winter food source produces positive growth rates that reach a maximum of $0.080 \mathrm{~mm} \mathrm{~d}^{-1}$ (Fig. 9B). This more than compensates for the brief period of low and negative growth rates that occur during the late fall and early winter and allows the krill to grow, or maintain its size, during the winter. Increased phytoplankton concentrations the following spring result in positive growth rates that range between 0.1 and $0.3 \mathrm{~mm} \mathrm{~d}^{-2}$ for the 3 phytoplankton concentrations.

The daily growth rates for $22 \mathrm{~mm}$ (Fig. 10A) krill are positive in late spring to early fall and negative in late fall and early winter prior to the availability of sea ice algae. The growth rate throughout the remainder of the winter is positive and increased phytoplankton concentrations in the spring result in a large increase in growth rate. The average growth rates for the $22 \mathrm{~mm}$ krill are $0.050,0.135$, and $0.170 \mathrm{~mm} \mathrm{~d}^{-1}$ for the outer shelf, coastal, and inner shelf phytoplankton time series. The average growth rate for these krill feeding on sea ice algae during late winter is $0.056 \mathrm{~mm} \mathrm{~d}^{-1}$, as compared to the mean shrinkage rate of $0.015 \mathrm{~mm} \mathrm{~d}^{-1}$ during the late fall and early winter.

The pattern of daily growth rates of adult krill (Fig. 10B) is similar to that for the $22 \mathrm{~mm}$ krill, except that the magnitude of the adult growth rates is smaller, being $0.070 \mathrm{~mm} \mathrm{~d}^{-1}$ for phytoplankton supported growth and $0.041 \mathrm{~mm} \mathrm{~d}^{-1}$ for sea ice algae supported growth. The mean winter shrinkage rate $\left(0.035 \mathrm{~mm} \mathrm{~d}^{-1}\right)$, however, is $53 \%$ larger than the rate for $22 \mathrm{~mm} \mathrm{krill}$. The adult krill incur more of a penalty from respiration losses, which results in less net production during favorable periods to support growth and more of a deficit during periods of unfavorable conditions.

\section{Model sensitivity}

The parameterization used to provide seasonal dependence for krill respiration (Fig. 5B) fits the few available observations (e.g. Torres et al. 1994a) and
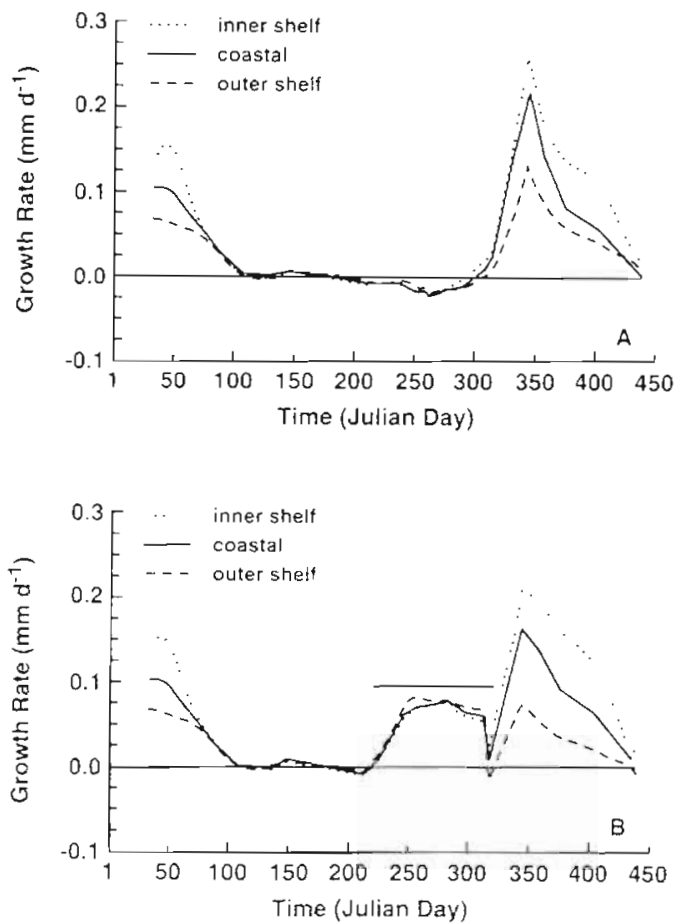

Fig. 9. Euphausia superba. Simulated growth rates of $2 \mathrm{~mm}$ krill exposed to the 3 phytoplankton time series (A) without and $(B)$ with feeding on sea ice algae during the winter. Thick horizontal line indicates the time during which sea ice algae are available to the $2 \mathrm{~mm}$ krill, mid-August (JD 226) to mid. November (JD 318) 
provides simulated winter growth rates that match observations. However, the model is sensitive to this formulation, and therefore it warrants examination.

Simulations in which only the standard respiration rate was used (e.g. identical winter and summer respiration rates) gave net shrinkage rates during the winter (Fig. 11) that were 2- to 3-fold larger than the rates obtained with a seasonally varying respiration factor. The adult krill (initial size, $45 \mathrm{~mm}$ ) shrank 35 to $41 \%$ from their maximum pre-winter size for the highest to lowest phytoplankton concentrations, respectively. The decrease in size took place over about 7 mo. Similar patterns are observed for the subadult and larval krill; however, the percentage change is not as large because respiration rates for the smaller krill are not as high. For the 2 and $22 \mathrm{~mm}$ krill, the net growth rates obtained with the non-seasonal respiration rates result in krill sizes that are considerably less than measured values and are unrealistically small.

\section{DISCUSSION}

\section{Winter food source}

For the simulations in which pelagic phytoplankton was the sole food source and metabolism was reduced in the winter (Fig. 7), the larval, subadult, and adult krill lost significant carbon and shrank in length during the winter. This produced unrealistically small krill by early spring (Fig. 7), especially for the subadult krill. This is in agreement with Torres et al. (1994b), who suggested that the impact of overwintering, assuming no feeding, was most severe for the smaller krill size classes. In contrast, the simulation in which sea ice biota was provided as a late winter, early spring food source (Fig. 8) produced annual growth trajectories for larval krill which are consistent with field length frequency measurements of late spring post-larval krill. The annual growth trajectory of subadult krill (starting at a length of $22 \mathrm{~mm}$ on February 1) also shows the importance of an alternate food source during the winter for this age group. These simulations strongly suggest that krill are feeding during the winter.

The type of food that krill can exploit during the winter is unknown. In this modeling study, the winter food was referred to as sea ice algae. Sea ice algae is plentiful in the Antarctic (e.g. Garrison et al. 1987) and krill have been observed to be associated with the undersurface of ice in winter-early spring and to feed by scraping algae from the ice suxface (O'Brien 1987. Marschall 1988, Daly 1990, Spiridonov 1992). However, there is evidence that krill also feed on copepods during winter (Huntley et al. 1994, Atkinson et al. 1999) and the ingestion of copepods by krill is clearly
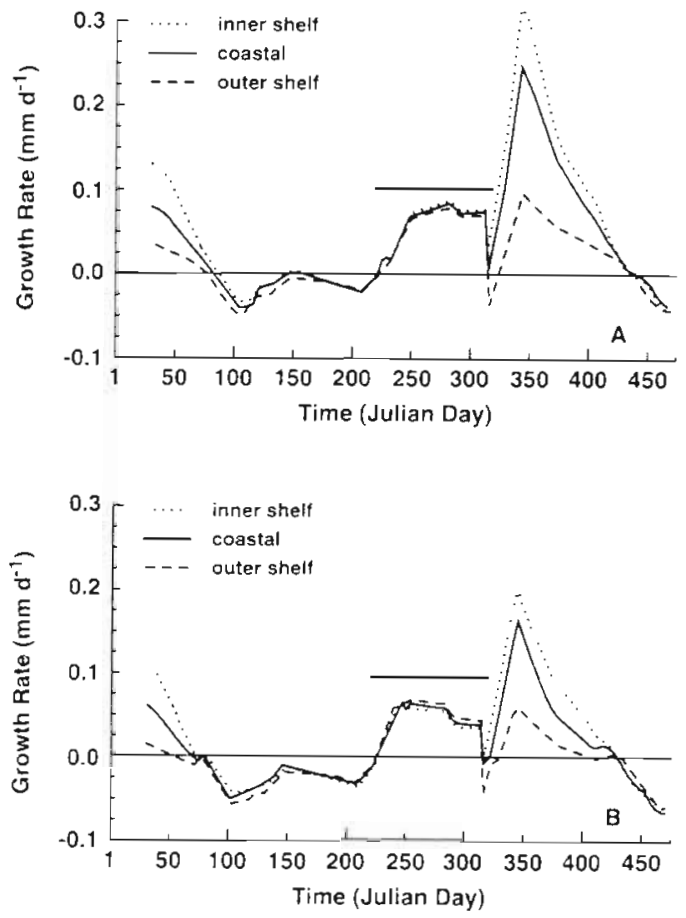

Fig. 10. Euphausia superba. Simulated growth rates of (A) $22 \mathrm{~mm}$ krill and (B) $45 \mathrm{~mm}$ krill exposed to the 3 phytoplankton time series and the sea ice algae time series. Thick horizontal line indicates the time during which sea ice algae are available to the 22 and $45 \mathrm{~mm}$ krill, mid-August (JD 226) to midNovember (JD 318)

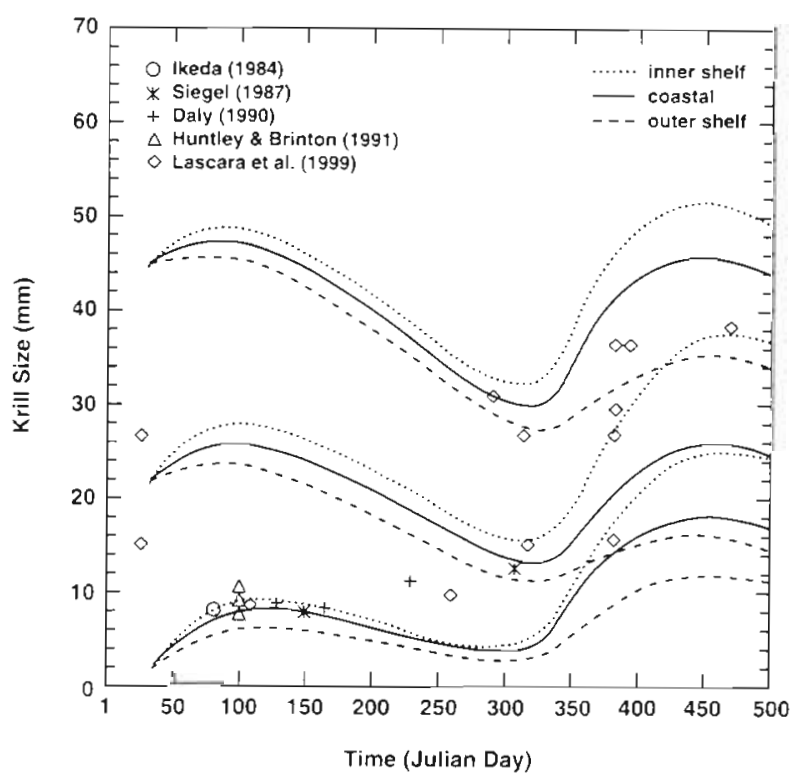

Fig. 11. Euphausia superba. Simulated time development of the dominant krill size class mode exposed to the 3 phytoplankton time series (cf. Fig. 6) and with no seasonal activity factor for initial krill sizes of $2 \mathrm{~mm}$ (lower 3 curves), $22 \mathrm{~mm}$ (middle 3 curves), and $45 \mathrm{~mm}$ (upper 3 curves). The simulations start on 1 February (JD 32) and the symbols represent observed krill sizes that were obtained from field and laboratory experiments 
demonstrated by laboratory (Ikeda \& Dixon 1982) and Antarctic summer field observations (Marr 1962, Price et al. 1988, Atkinson \& Snÿder 1997, Atkinson et al. 1999). Other heterotrophic food sources, such as microzooplankton, could also be exploited by krill during winter and cannibalism has been observed in laboratory animals (McWhinnie et al. 1979) Thus, switching to a predatory feeding behavior to meet their metabolic needs is not uncommon for krill.

A benthopelagic life style has been suggested as an overwintering strategy for krill in water less than $40 \mathrm{~m}$ (Kawaguchi et al. 1986). However, recent observations have shown dense benthopelagic aggregations of krill at depths of over $400 \mathrm{~m}$ (Gutt \& Siegel 1994), which is within the depth range of much of the Antarctic continental shelf. Also, vertical separation of older and larval krill in winter, with the older krill deeper, has been observed (Nordhausen 1994), which suggests that the older stages may use the benthos as a viable winter food source. Thus, it is possible that the benthos provides the needed food source for, at least, some part of the krill population during winter. In this case, the form of the winter food source used in the model (Fig. 6) would be different (perhaps less variable in time) for the older krill, but the need for a winter food source would still apply to all sizes of krill.

Studies of krill digestive enzymes show that they have the capacity to assimilate a wide variety of food (Mayzaud et al. 1985, 1987). Thus, the ability to exploit a wide range of food sources (e.g. omnivory) in either pelagic or benthic environments may be the real strategy that allows krill to successfully overwinter

\section{Growth curves and growth rates}

The growth forms derived from field observations of krill length frequency distributions (Fig. 1) show a seasonal pattern of growth, with rapid growth in the spring and summer and minimal or no net growth in winter. The simulated krill development obtained for the pelagic food only simulations (Fig 7) also show a similar seasonal pattern in growth, except that krill size and growth rate decrease during the winter. None of the field observations (Fig. 1) or the krill growth curves derived from laboratory measurements (Ikeda 1985) or those derived from theoretical considerations (Mauchline 1980) show a decrease in krill size during the winter. The inclusion of a winter food source produced simulations in which krill development (Fig. 8) matched the patterns derived from field and laboratory observations. The change in length for the $2 \mathrm{~mm}$ krill in these simulations (Fig. 8) during the different phases of growth matches that obtained from the field observations (Fig. 1). This cornparison provides support for the accuracy of the krill growth model and for the conclusion that krill feed during the winter and reduce their metabolic rates. This latter point is in agreement with experimental and theoretical studies (Torres et al 1994b) that showed that Antarctic euphausids undergo a marked reduction in metabolic rate during the winter

The simulated average growth rates for the subadult krill (initial size $22 \mathrm{~mm}$ ) exposed to the 3 pelagic phytoplankton time series are within the range of average summer growth rates $\left(0.105\right.$ to $\left.0.179 \mathrm{~mm} \mathrm{~d}^{-1}\right)$ estimated by Rosenberg et al. (1986) from an analysis of historical krill data obtained from the 'Discovery' investigations. They further suggested that maximum growth occurred during about 3 mo of the year, beginning in early spring. The simulated growth rates for the $22 \mathrm{~mm}$ krill (Fig, 10) show the same pattern.

The simulated growth trajectories for the larval and subadult krill show that for different food concentrations there can be an overlap in size with the smallersized krill originating from a larger size class. For example, subadult krill exposed to inner shelf food concentrations reach sizes that correspond to those of adult krill exposed to outer shelf food concentrations (Fig. 8). The merging of size classes for krill that are initially different sizes and are exposed to different food concentrations has implications for defining krill populations on the basis of cohort or size frequency analysis. These approaches must take into account the environmental conditions that produce the observed population structure

Nordhausen (1994) provides observations of krill size under ice during winter which show sizes for larval krill that are larger than those obtained in the simulation shown in Fig. 7 These observations suggest that the larval krill encountered food concentrations higher than those used in the simulations. This is consistent with the environment of Crystal Sound and Gerlache Strait, where the krill measurements were made, which are known regions of high primary production. Thus, the discrepancy in size between the observed and simulated larval kriil can be easily resolved by simply changing the timing, form, or magnitude of the winter food supply used in the simulations. For example, the short period of negative growth rate for the krill larvae in early winter (Fig 9B) before feeding on sea ice algae begins can be eliminated by providing a winter food source at an earlier time. Without this period of negative growth, the larvae will be larger at the start of winter, and continued growth, even slow growth, during the winter will produce larvae of the size reported by Nordhausen (1994). These results clearly illustrate the importance of obtaining accurate measurements of the structure and composition of the winter food for krill, and of quantifying the ingestion rate of krill on sea ice biota. 


\section{Implications for krill}

Recent studies have shown that good and poor krill year class success is related to sea ice conditions during the preceding winter (Siegel \& Loeb 1995, Loeb et al. 1997). The mechanisms underlying this dependence are many, but food availability is likely to be a strong factor. The simulations show clearly that the pelagic phytoplankton concentrations are not adequate to support krill growth during winter and that some supplemental form of food is needed in winter. The algae associated with sea ice provide one source of dependable food. However, it is possible that the presence of sea ice provides a habitat that is conducive to the accumulation of other food sources, such as copepods, that krill then exploit. In either case, winter sea ice conditions may determine the available food and hence krill recruitment. If so, this suggests that winter is the critical period in the krill life history. Thus, continuation of the trend in reduced winter sea ice cover in regions, such as the Antarctic Peninsula (Loeb et al. 1997), does not bode well for krill

Siegel (1988) described seasonal patterns of krill migration in which the larger animals moved inshore during the fall and winter. He suggested that this migration may be motivated by a need to reduce the intraspecific food competition between adults and larvae. The lower food supply of the outer shelf waters is insufficient to support the metabolism of the larger krill and these individuals have the ability to move. The simulations that used the outer shelf phytoplankton time series had the lowest growth rates (Fig. 10). Adult krill declined in size over the summer and early fall and growth of the subadult krill leveled off after a brief increase in summer (Fig. 7). Even the addition of a winter food supply did not substantially change the slow growth produced by feeding on the outer shelf phytoplankton during the rest of the year. This is consistent with experimental observations (Holm-Hansen \& Huntley 1984) that indicate that summer primary production in Antarctic pelagic waters can sustain the krill population maintenance metabolism, but may not provide for full growth of the individuals.

The smaller larval krill, however, cannot move as readily and can survive on the lower food supplies characteristic of the outer shelf (Figs, $6 \& 7$ ). Siegel (1988) suggested that the larger krill move inshore to take advantage of the higher pelagic phytoplankton concentrations or to graze on sea ice algae or sea-bed detritus in shallow water.

Other studies have noted the seasonal onshore migration of krill and the apparent disappearance of krill swarms during winter (Lascara et al. 1999). The absence of krill swarms may be related to food availability as the krill disperse under the ice during winter to feed.

\section{Model refinements}

In its current configuration, this size-structured, bioenergetically based growth model produces spring and summer growth rates for different krill size classes that are consistent with values observed experimentally and in field observations. The simulated annual growth cycle best matches observations when winter respiration rates are reduced and an additional winter food source (sea ice algae) is available, particularly for larval and subadult krill. The metabolic processes included in the model are based as much as possible on measurements available in the existing krill data base. However, the majority of these measurements are for adult krill and are from summer months when krill are actively feeding and growing. Measurements of metabolic processes of subadult and intermediatesized krill are needed to refine the parameterizations used in the model.

Krill spend 6 to 7 mo exposed to environmental conditions of reduced light, low pelagic food, and upper water column temperatures that are at freezing. Thus, it is reasonable to expect that krill adjust their metabolic processes and needs to compensate for these conditions. The model provides some insight as to how this compensation may occur. The constant respiration rate formulation, derived from laboratory measurements, results in simulations that give unrealistic krill growth (Fig. 11). It is only the inclusion of reduced respiration rate in the winter that allows simulations of krill growth that match observations. This strongly suggests that metabolic processes in krill do have a seasonal dependence. Conover \& Huntley (1991) show that feeding behavior and metabolism of several Arctic and Antarctic copepods have strong seasonal signals and suggest that light must somehow be involved in the transition from summer to winter metabolic rates and vice versa. However, they do not provide a mechanism by which this occurs. The need for measurements of krill metabolic processes during winter and during the transition times between summer and winter conditions is clear.

The current krill model does not include growth of reproductive tissue or spawning processes, which will alter the details of the growth pattern obtained from the simulations. Inclusion of these processes will not alter the overall patterns in krill growth or the need for a winter food supply. The addition of reproductive processes will, however, allow for investigation of the effect of winter food availability on krill reproductive success and allow for realistic simulations of year-toyear variations in krill recruitment.

Acknowledgements. Support for this research was provided by the U.S. National Science Foundation, Office of Polar Pro- 
grams grant OPP-9525806 (E.E.H.) and the Center for Coastal Physical Oceanography (C.M.L.) at Old Dominion University. We thank B. Fraser, K. Daly, M. Huntley, E. Murphy and J. Torres for many useful discussions on Antarctic krill growth and development. We also thank $\mathrm{H}$. Batchelder and 2 anonymous reviewers for constructive comments on this manuscript.

\section{LITERATURE CITED}

Astheimer HA (1986) A length class model of the population dynamics of the Antarctic krill Euphausia superba Dana. Polar Biol 6:227-232

Astheimer H, Krause H, Rakusa-Suszczewski S (1985) Modelling individual growth of the Antarctic krill Euphausia superba Dana. Polar Biol 4:65-73

Atkinson A, Snÿder R (1997) Krill-copepod interactions at South Georgia, Antarctica, I. Omnivory by Euphausia superba. Mar Ecol Prog Ser 160:63-76

Atkinson A, Ward P, Hill A, Brierley AS, Cripps GC (1999) Krill-copepod interactions at South Georgia, Antarctica, II. Euphausia superba as a major control on copepod abundance. Mar Ecol Prog Ser 176:63-79

Bargmann HE (1945) The development and life-history of adolescent and adult krill Euphausia superba. Discovery Rep 23:103-176

Clarke A (1984) Lipid content and composition of Antarctic krill, Euphausia superba Dana. J Crustac Biol 4 (Spec No 1): $285-294$

Clarke A, Morns DJ (1983) Towards an energy budget for krill: the physiology and biochemistry of Euphausia superba Dana. Polar Biol 2:69-86

Conover RJ. Huntley M (1991) Copepods in ice-covered seas - distribution, adaptations to seasonally limited food, metabolism, growth patterns and life cycle strategies in polar seas. J Mar Sys 2:1-42

Daly KL (1990) Overwintering development, growth and feeding of larval Euphausia superba in the antarctic marginal ice zone. Limnol Oceanogr 35:1564-1576

El-Sayed SZ (1994) Southern Ocean ecology: the BIOMA.SS perspective Cambridge University Press, Cambridge

Ettershank G (1983) Age structure and cyclical annual size change in the Antarctic krill, Euphausla superba Dana. Polar Biol 2:189-193

Fraser FC (1936) On the development and distribution of the young stages of krill, (Euphausia superba). Discovery Rep 14:1-192

Garrison DL, Buck KR (1989) The biota of Antarctic pack ice in the Weddell Sea and Antarctic Peninsula regions. Polar Biol 10:211-219

Garrison DL, Buck KR, Fryxell GA (1987) Algal assemblages in Antarctic pack ice and in jce-edge plankton. J Phycol $23: 564-572$

Gutt J, Siegel V (1994) Benthopelagic aggregations of krill (Euphausia superba) on the deeper shelf of the Weddell Sea (Antarctica). Deep-Sea Res 41:169-178

Hamner WM (1984) Aspects of schooling of Euphausia superba. J Crustac Biol 4 (Spec No 1):67-74

Hamner WM, Hamner PP, Strand SW, Gilmer RW (1983) Behavior of Antarctic krill, Euphausia superba: chemoreception, feeding, schooling and molting. Science 220: 433-435

Hofmann EE, Capella JE, Ross RM, Quetin LB (1992) Models of the early life history of Euphausia superba-Part I. Temperature dependence during the descent-ascent cycle. Deep-Sea Res 39.911-941

Holm-Hansen O, Huntley M (1984) Feeding requirements of krill in relation to food sources. J Crustac Biol 4 (Spec No 1): $156-172$

Holm-Hansen O, Mitchell BG (1991) Spatial and temporal distribution of phytoplankton and primary production in the western Bransfield Strait region. Deep-Sea Res 38:961-980

Holm-Hansen O, Mitchell BG, Hewes CD, Karl DM (1989) Phytoplankton blooms in the vicinity of Palmer Station, Antarctica. Polar Biol 10:49-57

Huntley M, Brinton E (1991) Mesoscale variation in growth and early development of Euphausia superba Dana in the western Bransfield Strait region. Deep-Sea Res 38: 1213-1240

Huntley ME, Nordhausen W (1995) Ammonium cycling by Antarctic zooplankton in winter. Mar Biol 121:457-467

Huntley ME, Nordhausen W, Lopez MDG (1994) Elemental composition, metabolic activity and growth of Antarctic krill Euphausia superba during winter. Mar Ecol Prog Ser $107: 23-40$

lkeda T (1981) Metabolic activity of larval stages of Antarctic krill. Antarct J US 16:161-162

Ikeda $\mathrm{T}$ (1984) Sequences in metabolic rates and elemental composition (C, N, P) during the development of Euphausia superba Dana and estimated food requirements during its life-span. J Crustac Biol 4(Spec No 1):273-284

Ikeda T (1985) Life history of Antarctic krill Euphausia superba: a new look from an experimental approach. Bull Mar Sci 37:599-608

Ikeda T, Bruce B (1986) Metabolic activity and elemental composition of krill and other zooplankton from Prydz Bay, Antarctic, during early summer (November-December). Mar Biol 92:545-555

Ikeda T, Dixon P (1982) Body shrinkage as a possible overwintering mechanism of the Antarctic krill (Euphausia superba Dana). Aust J Mar Freshw Res 33:71-76

Ikeda T, Dixon P (1984) The influence of feeding on the metabolic activity of Antarctic krill (Euphausia superba Dana). Polar Biol 3:1-9

Ikeda T, Kirkwood R (1989) Metabolism and body composition of two euphausiids (Euphausia superba and E. crystallorophias) collected from under the pack-1ce off Enderby Land. Antarctica. Mar Biol 100:301-308

Ikeda T, Mitchell AW (1982) Oxygen uptake, ammonia excretion and phosphate excretion by krill and other Antarctic zooplankton in relation to their body size and chemical composition. Mar Biol 71:283-298

Ishii $\mathrm{H}$, Omori $M$, Maeda $M$, Watanabe $\mathrm{Y}$ (1987) Metabolic rates and elemental composition of the Antarctic krill, Euphausia superba Dana. Polar Biol 7:379-382

Jacobs SS, Comiso JC (1997) Climate variability in the Amundsen and Bellingshausen Seas. J Climate 10:697-709

Kato M, Segawa S, Tanoue E, Murano M (1982) Filtering and ingestion rates of the Antarctic krill Euphausia superba Dana. Trans Tokyo Univ Fish 5:167-175

Kawaguchi K. Matsuda O, Ishikawa S, Naito Y (1986) The overwintering strategy of Antarctic krill (Euphausia superba) under the coastal fast ice off the Ongul Island in Lutzow-Holm Bay, Antarctica. Mem Natl Inst Polar Res (Tokyo) (Spec Issue) 44:67-85

Kottmeier ST, Sullivan CW (1987) Late winter primary productivity and bacterial production in sea ice and seawater west of the Antarctic Peninsula. Mar Ecol Prog Ser 36:287-298

Lascara CM, Hofmann EE, Ross RM, Quetī LB (1999) Seasonal variability in the distribution of Antarctic krill, Euphausia superba, west of the Antarctic Peninsula. Deep-Sea Res 46:925-949

Loeb V, Siegel V, Holm-Hansen O, Hewitt R, Fraser W, Trivelpiece $W$, Trivelpiece $S$ (1997) Effects of sea-ice extent 
and krill or salp dominance on the Antarctic food web Nature 387:897-900

Mackintosh NA (1972) Life cycle of Antarctic krill in relation to ice and water conditions. Discovery Rep 36:1-94

Marr JWS (1962) The natural history and geography of the Antarctic krill (Euphausia superba Dana). Discovery Rep $32: 33-464$

Marschall HP (1988) The overwintering strategy of the Antarctic krill under the pack-ice of the Weddell Sea Polar Biol 9:129-135

Mauchline J (1980) The biology of mysids and euphausiids Adv Mar Biol 18:1-681

Mayzaud P, Farber-Lorda J, Corre MC (1985) Aspects of the nutritional metabolism of two Antarctic euphausiids: Euphausia superba and Thysanoessa macrura. In: Siegfried WR, Condy PR, Laws RM (eds) Antarctic nutrient cycles and food webs. Springer-Verlag, Berlin, p 330-338

Mayzaud P, Van Wormhoudt A, Roche-Mayzaud O (1987) Spatial changes in the concentrations and activities of amylase and trypsin in Euphausia superba. A comparison between activity measurement and immunoquantitation Polar Biol 8:73-80

McWhinnie MA, Denys CJ, Parkin R, Parkin K (1979) Biological investigations of Euphausia superba Dana. Antarct J US 14:163-164

Miller DGM, Hampton I (1989) Krill aggregation characteristics: spatial distribution patterns from hydroacoustic observations. Polar Biol 10:125-134

Morris DJ (1984) Filtration of Euphausia superba Dana: underor over-estimates? J Crustac Biol 4 (Spec No 1):185-197

Morris DJ, Priddle J (1984) Observations on the feeding and moulting of the Antarctic krill, Euphausia superba Dana, in winter. Br Antarct Surv Bull 65:57-63

Nemoto $T$ (1959) Food of baleen whales with reference to whale movements. Scient Rep Whales Res Inst Tokyo 14: $149-290$

Nicol S, Stolp M, Cochran T, Geijsel P, Marshall J (1992) Growth and shrinkage of Antarctic krill Euphausia superba from the Indian Ocean sector of the Southern Ocean during summer. Mar Ecol Prog Ser 89:175-181

Nordhausen W (1994) Winter abundance and distribution of Euphausia superba, E. crystallorophias, and Thysanoessa macrura in Gerlache Strait and Crystal Sound, Antarctica. Mar Ecol Prog Ser 109:131-142

O'Brien DP (1987) Direct observations on the behaviour of Euphausia superba and Euphausia crystallorophias under pack-ice during the Antarctic spring of 1985. J Crustac Biol 7:437-448

Parkinson CL (1992) Interannual variability of monthly Southern Ocean sea ice distributions. J Geophys Res 97: $5349-5363$

Prézelin $\mathrm{BB}$, Hofmann EE, Klinck JM, Mengett C (in press) The linkage between Upper Circumpolar Deep Water (UCDW) and phytoplankton assemblages on the west Anarctic Peninsula continental shelf. J Mar Res

Price JH, Boyd KR, Boyd CM (1988) Omnivorous feeding

Editorial responsibility: Michael Landry (Contributing Editor), Manoa, Hawaii, USA behaviour of the Antarctic krill Euphausia superba. Mar Biol 97:67-77

Quetin LB, Ross RM (1985) Feeding by Antarctic krill, Euphausia superba: does size matter? In: Siegfried WR, Condy PR, Laws RM (eds) Antarctic nutrient cycles and food webs. Springer-Verlag, Berlin, p 372-377

Quetin LB, Ross RM (1989) Effects of oxygen, temperature and age on the metabolic rate of the embryos and early larval stages of the Antarctic krill Euphausia superba Dana. J Exp Mar Biol Ecol 125:43-62

Quetin LB, Ross RM (1991) Behavioral and physiological characteristics of the Antarctic krill, Euphausia superba. Am Zool 31:49-63

Quetin LB, Ross RM, Clarke A (1994) Krill energetics: seasonal and environmental aspects of the physiology of Euphausia superba. In: El-Sayed S (ed) Southern Ocean ecology: the BIOMASS perspective. Cambridge University Press, Cambridge, p 165-184

Rosenberg AA, Beddington JR, Basson M (1986) Growth and longevity of krill during the first decade of pelagic whaling. Nature 324:152-154

Rudd JT (1932) On the biology of southern Euphausiidae. Hvalradets Skr 2:1-1.05

Schnack SB (1985) Feeding by Euphausia superba and copepod species in response to varying concentrations of phytoplankton. In: Siegfried WR, Condy PR, Laws RM (eds) Antarctic nutrient cycles and tood webs. SpringerVerlag, Berlin, p 311-323

Siegel V (1987) Age and growth of Antarctic Euphausiacea (Crustacea) under natural conditions. Mar Biol 96:483-495

Siegel V (1988) A concept of seasonal variation of krill ( $E u$ phausia superba) distribution and abundance west of the Antarctic Peninsula. In: Sahrhage D (ed) Antarctic Ocean and resource variability. Springer-Verlag, Berlin, p 219-230

Siegel V, Loeb V (1995) Recruitment of Antarctic krill Euphausia superba and possible causes for its variability Mar Ecol Prog Ser 123:45-56

Smith WO Jr, Sakshaug E (1990) Polar phytoplankton. In: Smith WO Jr (ed) Polar oceanography. Part B. Chemistry, biology, and geology. Academic Press, San Diego, p 477-525

Spiridonov VA (1992) Distribution and biological properties of the Antarctic krill Euphausia superba Dana during winter Weddell Gyre study (WWGS) 1989. Proc Natl Inst Polar Res, Symp Polar Biol 5:55-64

Stretch JJ, Hamner PP, Hamner WH, Michel WC, Cook J, Sullivan CW (1988) Foraging behavior of Antarctic krill Euphausia superba on sea ice microalgae. Mar Ecol Prog Ser $44: 131-139$

Torres JJ, Aarset AV, Donnelly J, Hopkins TL, Lancraft T, Ainley DG (1994a) Metabolism of Antarctic micronektonic Crustacea as a function of depth occurrence and season. Mar Ecol Prog Ser 113:207-219

Torres JJ, Donnelly J, Hopkins TL, Lancraft TM, Aarset AV, Ainley DG (1994b) Proximate composition and overwintering strategies of Antarctic micronektonic Crustacea. Mar Ecol Prog Ser 113:221-232

Submitted: October 20, 1998; Accepted: July 25, 1999

Proofs received from author(s): February 25, 2000 